\title{
Physiological responses of reared sea bream (Sparus aurata Linnaeus, 1758) to an Amyloodinium ocellatum outbreak
}

\begin{tabular}{|r|l|}
\hline Journal: & Journal of Fish Diseases \\
\hline Manuscript ID & JFD-2016-283 \\
\hline Manuscript Type: & Original Manuscript \\
\hline Date Submitted by the Author: & 07-Oct-2016 \\
\hline Complete List of Authors: & $\begin{array}{l}\text { Moreira, Márcio; IPMA - Portuguese Institute for the Sea and Atmosphere, , } \\
\text { EPPO - Aquaculture Research Station } \\
\text { Schrama, Denise; Universidade do Algarve, FCT } \\
\text { Soares, Florbela; IPMA, } \\
\text { Wulff, Tune; Danmarks Tekniske Universitet, The Novo Nordisk Foundation } \\
\text { Center for Biosustainability } \\
\text { Pousão-Ferreira, Pedro; Instituto Portugues do Mar e da Atmosfera, EPPO } \\
\text { Rodrigues, Pedro; FCT }\end{array}$ \\
\hline Keywords: & $\begin{array}{l}\text { Amyloodinium ocellatum, gilthead sea bream, proteomics, physiological } \\
\text { responses }\end{array}$ \\
\hline
\end{tabular}




\title{
Physiological responses of reared sea bream (Sparus aurata Linnaeus, 1758) to an Amyloodinium ocellatum outbreak
}

\author{
Márcio Moreira ${ }^{1}$, Denise Schrama ${ }^{2}$, Florbela Soares ${ }^{1}$, Tune Wulff ${ }^{3}$, Pedro Pousão-Ferreira ${ }^{1}$, Pedro \\ Rodrigues $^{2 *}$ \\ ${ }^{1} I P M A$ - Portuguese Institute for the Sea and Atmosphere, EPPO - Aquaculture Research Station, Av. 5 de Outubro s/n, \\ 8700-305 Olhão, PORTUGAL \\ ${ }^{2}$ CCMAR - Centre of Marine Sciences, University of Algarve, Campus de Gambelas, 8005-139 Faro, PORTUGAL \\ 3 The Novo Nordisk Foundation Center for Biosustainability, Technical University of Denmark, Kogle Allé 6 , \\ 2970 Hørsholm, DENMARK \\ * Corresponding author (e-mail: pmrodrig@ualg.pt, Adress: CCMAR - Centre of Marine Sciences, University of \\ Algarve, Campus de Gambelas, 8005-139 Faro, PORTUGAL, Contacts: +351289800100, Ext:7855)
}

\begin{abstract}
Amyloodiniosis represents a major bottleneck for semi-intensive aquaculture production in Southern Europe, causing extremely high mortalities. Amyloodinium ocellatum is a parasitic dinoflagellate that can infest almost all fish, crustacean and bivalves that live within its ecological range. Fish mortalities are usually attributed to anoxia, associated with serious gill hyperplasia, inflammation, haemorrhage and necrosis in heavy infestations; or with osmoregulatory impairment and secondary microbial infections due to severe epithelial damage in mild infestation. However, physiological information about the host responses to $A$. ocellatum infestation is scarce. In this work we analysed the proteome of gilthead sea bream (Sparus aurata) plasma and relate it with haematological and immunological indicators, in order to enlighten the different physiological responses when exposed to an A. ocellatum outbreak. Using 2D-DIGE, immunological and haematological analysis and in response to the A. ocellatum contamination we have identified several proteins associated with acute phase response, inflammation, lipid transport, homeostasis, and osmoregulation, wound healing, neoplasia, and iron transport. Overall, this preliminary study revealed that amyloodiniosis affects some fish functional pathways as revealed by the changes in the plasma proteome of $S$. aurata, and that the innate immunological system is not activated in the presence of the parasite.
\end{abstract}


Keywords: Amyloodinium ocellatum, gilthead sea bream, proteomics, physiological responses

Running title: Fish physiological responses to amyloodiniosis

\section{Introduction}

Nowadays, aquaculture is the food industry with the highest annual growth rate $(5,8 \%$ average growth rate between 2005-2014, 4,9\% in 2014) (FAO, 2014; FAO, 2016). The World Bank (2013) and Lem, Bjorndal \& Lappo (2014) predicts a growth of more than 50\% until 2030, supplying over $60 \%$ of fish destined for direct human consumption. However, a higher development of aquaculture is constrained by different causes.

Fish diseases are one of the main problems in aquaculture, especially in intensive fish farming, representing severe annual costs to producers (Murray \& Peeler, 2005). Parasitic diseases caused by obligate or opportunistic pathogens can have a major impact on global finfish and shellfish aquaculture, representing a key constraint to production, sustainability and economic viability of aquaculture facilities in many regions (Shinn, Pratoomyot, Bron, Paladini, Brooker \& Brooker, 2015). Also global warming tends to increase the frequency of the outbreaks by increase of the ecological range of diseases and abundance of parasites, and a diminished immunocompetence in the hosts (Marcogliese, 2008; FOESA, 2013; Cristina García Diez \& Remiro Perlado, 2014; FAO, 2015; Mohan, 2015).

Amongst them, amyloodiniosis is a parasitic disease that represents a major threat for semiintensive aquaculture, especially in Southern Europe, being one of the most serious impediments for 
the production of several warm water aquaculture species (Noga, Ullal. Corrales \& Fernandes, 2011).

This disease is caused by the dinoflagellate Amyloodinium ocellatum (Brown), that provokes fast and asymptomatic outbreaks, with acute morbidity and mortality (around 100\%) in brackish and marine warm water fish on different aquaculture facilities worldwide (Becker, 1977; Lawler, 1980; Paperna, Colorni, Ross \& Colorni, 1981; Lauckner, 1984; Noga, 2006; Soares, Quental-Ferreira, Cunha \& Pousão-Ferreira, 2011). This parasite has also the capacity for hyperparasite some parasites of fish like Neobenedenia melleni (MacCallum) (Monogenea: Capsalidae) in gilthead sea bream (Sparus aurata L.) (Colorni, 1994), and inflict moderate to intense tissue reaction in several commercially important shrimp species (Aravindan, Chaganti \& Aravindan, 2007). The affected producers can have a major economic impact, as demonstrated by the reported cases of A. ocellatum in a milkfish (Chanos chanos Forsskål) hatchery in 2004 (Cruz-Lacierda, Maeno, Pineda \& Matey, 2004) and a case in Nile tilapia (Oreochromis mossambicus W. K. H. Peters) in the Salton Sea, California, United States (Kuperman \& Matey, 1999) had a total cost loss of 20,000 USD and 6-77 million USD respectively (Shinn et al., 2015).

Biologically A. ocellatum is a dinoflagellate with a life cycle that comprises three stages: trophont (parasitic state, attached to fish gills and skin), tomont (encapsulated state, a cyst that develops after the trophont leaves the fish); and dinospores (free living state, released from the tomont) (Kuperman \& Matey, 1999; Landsberg, Blakesley, Reese, Mcrae \& Forstchen, 1988; Woo, 2007). Each tomont can produce up to 256 dinospores in 3 days at $25^{\circ} \mathrm{C}$, each one capable to infect a new host and produce a trophont (Brown \& Hovasse, 1946).

The symptomatology of this disease is characterized by sudden changes in fish behaviour, with jerky movements, swimming at the water surface, decreased appetite, increased respiratory rate and gathering at the surface or in areas with higher dissolved oxygen concentrations (Soares et al., 
2011). Fish mortalities are normally attributed to anoxia (associated with serious gill hyperplasia, inflammation, haemorrhage and necrosis) in heavy infestations (Lawler, 1980). However, there are reports of high mortalities associated with mild infestations that could be associated with osmoregulatory impairment and secondary microbial infections due to severe epithelial damage (Noga, 2012). Physiological information about the responses from the host to A. ocellatum infestation is limited, and is mainly available in some publications about antimicrobial protein expression in gills and skin (Colorni, Ullal, Heinisch \& Noga, 2008; Noga, Silphaduang, Park, Seo, Stephenson \& Kozlowicz, 2009; Corrales, Mulero, Mulero \& Noga, 2010; Noga et al., 2011) and general immunological responses of the host to A. ocellatum (Smith, Levy \& Noga, 1992; Smith, Levy \& Noga, 1994; Noga, Fan \& Silphaduang, 2002; Alvarez-Pellitero, 2008; Woo \& Ardelli, 2014).

These reported immunological reactions and the development of resistance to A. ocellatum by fish previously contaminated with the parasite (Cobb, Levy \& Noga, 1998) means that an immunological approach can be used to access a possible immunological response from the organism to A. ocellatum presence. Lysozyme makes part in an extensive battery of defence mechanisms in fish, such as bacteriolysis and opsonization of the bacterial wall, and it is present in lymphoid tissues, mucus, plasma, and other body fluids (Magnadottir, 2006). It's a membranolitic enzyme that measures the immune system activity against bacteria and an important index of innate immunity of fish (Saurabh \& Sahoo, 2008). Lysozyme can provide us information about the activation of the innate immune system and about the existence of a possible secondary bacterial infections due to severe epithelial damage (Corrales et al., 2010).

Taking in account the damage that A. ocellatum can cause in the gills, haematological analysis could be a good approach for accessing possible responses from fish to a parasite outbreak. Haematological analysis can be especially important as a direct or inferential indicator to monitor fish health, since they can provide information related to fish tolerance to stress, metabolic 
disorders, reproductive dysfunctions or pathologies, like the ones caused by external agents such as parasites (Clauss, Dove \& Arnold, 2008; Del Rio-Zaragoza, Hernandez-Rodriguez \& BuckleRamirez, 2008; Buscaino, Filiciotto, Buffa, Bellante, Di Stefano, Assenza, Fazio, Caola \& Mazzola, 2010; Del Rio-Zaragoza, Fajer-Avila, Almazan-Rueda \& Abdo de la Parra, 2011). Because of this, these kind of analyses are being gradually introduced to determining the health status of these animals (Percin \& Konyalioglu, 2008).

In recent years a large amount of large-scale approaches in biology that promise to revolutionize systems-level understanding of cellular and organism functions has been developed. These fields, referred to as "omics", can assess the structure and functioning of organisms with a comprehensive and unprecedented level of detail (Joyce \& Palsson, 2006). Amongst these, one of the most promising as a potentially new approach to conventional methods is Proteomics (Alves, Cordeiro, Silva, Richard, de Vareilles, Marino, Di Marco, Rodrigues \& Conceição, 2010). Proteomics constitutes one of the new best approaches for better understanding fish diseases and epidemiology, giving us an insight on the protein abundance and modification patterns in the organism (Rodrigues, Silva, Dias \& Jessen, 2012; Peng, 2013). This information can be extremely useful in the study of fish physiological responses to the parasite A. ocellatum, allowing a better insight of the mechanisms involved in the process and the identification of possible biomarkers, since protein profiles appear to be specific to particular stressors (Alves et al., 2010; Cox \& Mann, 2011). Two of the most common techniques are 2D Fluorescence Difference Gel Electrophoresis (DIGE), and shotgun techniques like iTRAQ or RP-HPLC (Martyniuk, Alvarez \& Denslow, 2012).

Blood plasma has been used in proteomics studies because is considered a biological fluid of primary importance for analysis, since it is a solution with several proteins and peptides bathing cells and tissues of the whole organism, acting as a mirror/reporter of physiological or pathological conditions (Isani, Andreani, Carpenè, Di Molfetta, Eletto \& Spisni, 2011) and hence should be a good source of biomarkers in an A. ocellatum outbreak. 
Gilthead sea bream was used in this experiment due to its economic importance in Southern Europe aquaculture. This species has been used for several years as a model in marine fish physiology because of the vast knowledge accumulated, especially to several ambiental stressors (Isani et al., 2011).

In this work we will analyse and compare the proteome of gilthead sea bream plasma and analyse haematological and immunological indicators, to enlighten the different physiological responses when exposed to an A. ocellatum outbreak.

\section{Material and Methods}

\subsection{Fish and rearing conditions}

One hundred and fourteen gilthead sea breams, with a mean body weight of $87.2 \pm 17.1 \mathrm{gr}$ and a mean body length of $17.73 \pm 1.14 \mathrm{~cm}$ were reared in duplicate $200 \mathrm{~L}$ rectangular plastic tanks (Control - fish without parasites, T1 - fish with A. ocellatum, T2 - fish with a lower amount of $A$. ocellatum and monogenic parasites like Dactylogirus sp. or Lamellodiscus sp. N=19), at Aquaculture Research Centre, National Institute for the Sea and Atmosphere (EPPO-IPMA, Olhão, Portugal). Fish were kept at $22 \pm 0.2^{\circ} \mathrm{C}$, for 5 days for acclimation in closed recirculation seawater systems, artificial aeration and natural photoperiod. Fish on tanks from T1 and T2 were infected with A. ocellatum tomonts obtained from an amyloodiniosis outbreak in an EPPO - IPMA earthen pond. 


\subsection{Sampling}

Two samples of water, one at the beginning and other at the end of the experience, were obtained in order to access the number of dinoflagellates per milliliter in the tanks by the Utermöhl method for quantitative phytoplankton analysis (Karlson, Caroline \& Bresnan, 2010).

Fish contamination was accessed by microscopical observation of a wet mount of the first two branchial arches from two fish killed with a cut in the spine, at 12 and $18 \mathrm{~h}$ after contamination (according to preliminary tests).

At $18 \mathrm{~h}$, when the contamination reached 500 parasites per branchial arc, 4 random fish from each tank were selected, in order to get 8 biological replicates per treatment. They were then anesthetized with 2-phenoxyethanol (Sigma Aldrich), and approximately $1 \mathrm{ml}$ of blood was withdrawn using syringes heparinized with $1 \%$ EDTA. This process was performed in less than 3 minutes. The blood was then centrifuged at $2500 \mathrm{rpm}$ for 10 minutes, and plasma was collected and kept at $-80^{\circ} \mathrm{C}$ for subsequent proteomic analysis.

For haematological and immunological analysis, blood samples were collected from all the remaining fish ( $\mathrm{N}=11)$ from Control, $\mathrm{T} 1$ and $\mathrm{T} 2$. Blood was taken by caudal vein puncture with a 1 $\mathrm{ml}$ heparinized syringe. Collection of blood samples was completed within 5 min of capturing the fish to minimize handling stress.

Infected fish were then killed with an overdose of anesthetic according with the EU Directive 2010/63/EU for animal experiments. 
The first two branchial arches of all the fishes $(\mathrm{N}=15)$ were also withdrawn for parasite counting by microscopical observation.

\subsection{Haematological analysis}

The determination of the haematocrit (HCT) value was made by the methodology described by Soares, Leitão, Moreira, Teixeira de Sousa, Almeida, Barata, Feist, Pousão-Ferreira \& Ribeiro (2012). The rest of the blood $(\mathrm{N}=11)$ was transferred to a clean slide and was used for haematological determination. Blood cells were air dried and stained with Wright-Giemsa. The number of erythrocytes, thrombocytes, leucocytes, monocytes and granulocytes were counted microscopically. T-student statistical analysis of the data was performed in IBM SPSS Statistics for Windows, Version 21.0. (IBM Corp. Released 2012. Armonk, NY: IBM Corp).

\subsection{Immunological analysis}

Plasma lysozyme activity was assessed using a turbidimetric assay (Ellis, 1990) adapted to 96-well microplates. In summary, lyophilized Micrococcus lysodeikticus (Sigma) were dissolved in in 0.05 M sodium phosphate buffer at $\mathrm{pH} 6.2\left(0.3 \mathrm{mgml}^{-1}\right)$, and this solution was used as a substrate for the plasma lysozyme. Triplicates of each sampled fish plasma (15 $\mu$ l) from Control, T1 and T2 $(\mathrm{N}=11)$ were added to $250 \mu \mathrm{l}$ of the bacterial suspension, and the reduction in absorbance at $450 \mathrm{~nm}$ was measured at 0.5 and $4.5 \mathrm{~min}$ of reaction. A unit of lysozyme activity was defined as the amount of enzyme that caused a decrease in absorbance of 0.001 per min. T-student statistical analysis of the data was performed in IBM SPSS Statistics for Windows, Version 21.0. (IBM Corp. Released 2012. Armonk, NY: IBM Corp). 
Prior to protein separation, quantification of protein in plasma was performed using the Bradford assay (Bio-Rad), using bovine serum albumin as standard. Two-dimensional difference gel electrophoresis was used to separate proteins according to their isoelectric point (pI) in the first dimension and their molecular weight $(\mathrm{Mw})$, considered as second dimension, using fluorescent dyes. Samples were adjusted to $\mathrm{pH} 8.5$ with $0.1 \mathrm{M} \mathrm{NaOH}$ and $50 \mu \mathrm{g}$ of proteins were minimally labeled with 400 pmol of fluorescent amine reactive cyanine dyes freshly dissolved in anhydrous dimethylformamide following manufacturer's instructions (5 nmol labeling kit, GE Healthcare). Labeling was performed on ice for 30 minutes in the dark and quenched with $1 \mathrm{mM}$ of lysine for 10 min. Four samples per treatment (Control, T1 and T2) were labelled with Cy3 and four with Cy5 to reduce impact of label differences, while an internal standard consisting of equal amounts of protein from all samples was labeled with Cy2.

\subsection{Protein separation by $2 \mathrm{D}$ gel electrophoresis}

Labeled proteins from each treatment plus $50 \mu \mathrm{g}$ of internal standard were mixed together and rehydration buffer (6M urea, 2M thiourea, 4\% CHAPS, $0.02 \%(\mathrm{w} / \mathrm{v}) \mathrm{DTT}, 0.002 \%$ bromophenol blue, $0.5 \%$ (v/v) IPG buffer $\mathrm{pH} 4-7)$ was added to complete $450 \mu \mathrm{l}$. Rehydration was performed passively for 14 hours using IPG box (GE Healthcare) on $24 \mathrm{~cm}$ Immobiline ${ }^{\mathrm{TM}}$ DryStrips (GE Healthcare) with linear $\mathrm{pH} 4-7$, continued by isoelectric focusing (IEF) in 5 steps: at $500 \mathrm{~V}$ gradient $1 \mathrm{hr}$, at $500 \mathrm{~V}$ step-n-hold $1 \mathrm{hr}$, at $1000 \mathrm{~V}$ gradient $1 \mathrm{hr}$, at $8000 \mathrm{~V}$ gradient $3 \mathrm{hrs}$, and at $8000 \mathrm{~V}$ stepn-hold for a total of $60000 \mathrm{Vhr}$. Before second dimension, strips were reduced and alkylated using 6 $\mathrm{ml}$ of an equilibration buffer (1.5M Tris- $\mathrm{HCl} \mathrm{pH} 8.8,6 \mathrm{M}$ urea, 30\% (v/v) glycerol, 0.007M SDS, a few grains of bromophenol blue) with $1 \%(\mathrm{w} / \mathrm{v})$ DTT or $2.5 \%(\mathrm{w} / \mathrm{v})$ iodoacetamide respectively for 15 min each. Strips with the samples and internal standard were loaded onto $12.5 \%$ Tris-HCl SDSPAGE gels and run in an Ettan DALTsix Vertical System at $10 \mathrm{mAgel}^{-1}$ for 1 hour followed by 60 
$\mathrm{mAgel}^{-1}$ using a standard Tris-Glycine-SDS running buffer, until the bromophenol blue line reaches the end of the gel.

\subsection{Gel image acquisition, analysis and statistics}

Gels were scanned on a Typhoon scanner 9400 (GE Healthcare) using three laser emission filters (520BP40 for $\mathrm{Cy} 2,580 \mathrm{BP} 30$ for $\mathrm{Cy} 3$ and $670 \mathrm{BP} 30$ for $\mathrm{Cy} 5$ ) at $100 \mu \mathrm{m}$ resolution. Images were analyzed with Progenesis SameSpots ${ }^{\mathrm{TM}}$ 2DE gel analysis software (Nonlinear Dynamics, United Kingdom) with filters for average normalized volume $\leq 10,000$ and spot area $\leq 500$. A one-way ANOVA was then applied on resulting protein abundance data (expressed in relation to the internal standard), having considered proteins with a $\mathrm{P}<0.05$ as being likely to be affected by the presence of A. ocellatum. All the significantly different spots were then subjected to a Tukey test, to rule out false positives resultant of protein abundance data. These statistical tests were made using $\mathrm{R}$ package (version 3.1.1) (R Core Team, 2013). From these spots, we selected the ones that presented differences between $\mathrm{T} 1$ and the other treatments (indicators of a specific reaction from the host to $A$. ocellatum), and the spots with higher average normalized volume that presented differences between $\mathrm{T} 1$ and $\mathrm{T} 2$ versus control (possible generalist indicators of a response from the host to ectoparasites). The selected spots were then manually excised from preparative gels post-stained with colloidal Coomassie Blue, for digestion and identification.

\subsection{Protein identification by MS analysis of peptides and Database search}

The proteins of the previously selected spots were identified by LC-MS/MS. Proteins were broken up into peptides by tryptinization, using the following methodology: Spots of interest were washed in $200 \mu \mathrm{l}$ of $100 \mathrm{mM}$ ammonium bicarbonate for 30 minutes to 1 hour on a shaker. Wash was discarded and $200 \mu \mathrm{l}$ of $50 \%$ acetonitrile / $100 \mathrm{mM}$ ammonium bicarbonate was added for 30 
minutes to 1 hour on a shaker. Wash was discarded and $50 \mu 1$ acetonitrile was added to the spots and left to actuate for 10 minutes. Solvent was discarded and spots are dried on a vacuum centrifuge for at least 30 minutes. Twenty $\mu 1$ of trypsin was added to each spot and allowed to digest overnight at $37^{\circ} \mathrm{C}$. After digestion $20 \mu \mathrm{l}$ of $5 \% \mathrm{FA}$ acid is added to the gel pieces and left to incubate on a shaker for 20 minutes. Forty $\mu 1$ of acetonitrile was added and left again on a shaker for 20 minutes. Liquid was transferred to a new microplate and dried on a vacuum centrifuge for a couple of hours. Then the peptide containing samples were run on a SYNAPT G2 HDMS mass spectrometer (Waters) coupled to a nanoAcquity UPLC system (Waters). Each sample was first trapped using a C18 trap column (C18 symmetry, $5 \mu \mathrm{m}, 180 \mu \mathrm{m} \times 20 \mathrm{~mm}$, Waters) and subsequently separated using a C18 nanoanalytical column (BEH130 C18 $1.7 \mu \mathrm{m}, 75 \mu \mathrm{m}$ x $200 \mathrm{~mm}$, Waters). During separation the flow rate of the loading pump was $0.3 \mu \mathrm{min}^{-1}$, using two mobile phases, A (deionized water with $0.1 \%$ formic acid) and B (Acetonitrile with $0.1 \%$ formic acid). During the 20 minutes gradient B was increased from 1 to $45 \%$. Data was collected on the mass spectrometer employing the positive ion MSe acquisition method (cycle time $0.8 \mathrm{~s}$ ). The resulting data were used as input in the ProteinLynxGlobalServer (PLGS v.2.5.3). First spectra were generated using the following parameters:

- Chromatographic peak width: Automatic

- MS TOF resolution: Automatic

- Lock Mass for charge 1: 556.2771Dae ${ }^{-1}$

- Lock Mass Window: 0.25 Da

- Low energy threshold: 80 Counts

- Elevated energy Threshold: 20 Counts

- Intensity threshold: 750 Counts

Raw data files Protein identification was obtained by using the Protein Lynx Global Server (PLGS) software v2.5.3 (Water corporation) using the in-build MSe search function against the databases 
described below. The search parameters were trypsin as enzyme, carboxamidomethyl on cysteine as fixed modification and oxidation of methioninen as partial modification while allowing one missed cleavage.

First searches were done against a database generated from uniprot including all reviewed proteins from the taxonomy Actinopterygii [7898]. In the database was added a list of known contaminants. If not hit were obtained searches were done against the database all proteins from the taxonomy Actinopterygii [7898]. In the database was added a list of known contaminants.

Finally, all hits were manually inspected for verification and to avoid false positives.

\section{Results}

\subsection{Amyloodinium ocellatum dinospore and trophont counts}

The dinospore counts in the different treatments are indicated in Figure 1.

Suggested location for figure 1

The number of dinospores per $\mathrm{ml}$ in $\mathrm{T} 1$ and $\mathrm{T} 2$ tanks was very high, indicating a large potential infective population of parasites present in the tanks. No parasites were found in the control tank. After 18 hours, the observation of the branchial arches indicated that Control tanks had no $A$. ocellatum trophonts in the gills. T1 had a total of $497.25 \pm 14.50$ A. ocellatum trophonts per branchial arc, and T2 had 50.52 \pm 10.96 monogeneans (mainly Dactylogirus sp.) and 79.13 $\pm 20.71 \mathrm{~A}$. ocellatum trophonts per branchial arc. These results assure that there was no cross-contamination to the Control tanks, and that the parasite populations for $\mathrm{T} 1$ and $\mathrm{T} 2$ are the expected for the experiment. 


\subsection{Hematological analysis}

The obtained results for the HCT analysis are described in Table 1.

Suggested location for Table 1

The obtained results for the cell count results are described in the Table 2.

Suggested location for Table 2

The HCT and cell count values did not present any statistical differences between treatments.

\subsection{Immunological analysis}

The obtained results for the lysozyme analysis are described in Figure 2.

Suggested location for figure 2

The lysozyme values did not present any statistical differences between treatments. Moreover, the values obtained were at the minimum, and there was bacterial growth in several samples. This explains the dispersion of the data. This also means that lysozyme wasn't active in almost all the samples. 


\subsection{Proteomic analysis}

The plasma proteome analysis revealed a total of 2078 different protein spots, from which 752 had differences in the protein spot volume between treatments. This number was reduced to 397 protein spots after Tukey test. From these, we have selected the protein spots indicated in the 2D gel presented in Figure 3, following the methodology described in Material and Methods. These protein spots were selected based on their volume differences. Volume differences between T1 and the rest of the treatments might indicate a specific reaction of the organism to A. ocellatum. Volume differences between T1, T2 and Control might indicate a generalist response to ectoparasites. The protein spot that presented a higher volume difference between all the treatments was also selected.

Suggested location for figure 3

\subsection{Protein spot sequencing and identification}

The selected individual peptides that were identified by LC-MS/MS were used to perform a BLAST search restricted to the Actinopterygii class. In our work we have obtained one match for Apolipoprotein A-I, two matches for Hemopexin, and matches for Uncharacterized protein OS Takifugu rubripes GN LOC101068102 PE 4 SV 1, Uncharacterized protein OS Lepisosteus oculatus GN KRT9 2 of 3 PE 3 SV 1 and Estrogen-regulated protein OS Sparus aurata PE 2 SV 1. The obtained results, spot volume profile and possible main function are summarized in in Table 3 .

Suggested location for table 3 


\section{Discussion}

Since an outbreak of A. ocellatum is normally associated with mortality, mainly due to anoxia, or osmoregulatory impairment and secondary microbial infections due to severe epithelial damage (Lawler, 1980; Noga, 2012), a high population of dinospores of the parasite was needed, in order to maximize the hypothesis of expected changes in the fold of proteins related with the physiological response of the host to the parasite.

As mentioned in the results section, the number of dinospores per ml in $\mathrm{T} 1$ and $\mathrm{T} 2$ tanks was very high, indicating a large potential infective population of parasites present in the tanks. However, the number of trophonts of $A$. ocellatum attached to the branchia in T1 was high and the load of $A$. ocellatum in $\mathrm{T} 2$ was low. There is no reference in the literature to a lower load of this parasite in the presence of other parasites, like trematodes. This lower load of A. ocellatum trophonts in T2 can have two explanations: a) intraspecific competition between parasites for space in the branchia (Vidal-Martínez, Pech, Sures, Purucker \& Poulin, 2009; Mladineo, Petrić, Šegvić \& Dobričić, 2010; Loot, Poulet, Brosse, Tudesque, Thomas \& Blanchet, 2011); or b) an unspecific reaction from the immune system to the presence of ectoparasites (Bayne \& Gerwick, 2001; Tort, Balasch \& MacKenzie, 2004; Tort, 2011), that constitutes an obstacle to the fixation of A. ocellatum dinospores. Nevertheless, this lower count in $\mathrm{T} 2$ allows us to use it as a treatment condition with lower parasite load, useful to discard possible false positives, and also as an indicator of generalist responses to the parasite (volume differences between T1, T2 and Control).

In the haematological analysis, it is described by various authors that the presence of A. ocellatum provokes several lesions and hyperplasia of the respiratory epithelium accompanied by lamellar fusion, detachment of the epithelium, venous sinus dilatation, aneurysm formation and rupture of the lamellar epithelium, haemorrhage, necrosis and lymphocytic inflammatory reaction (Lawler, 
1980; Noga, 2012). Moreover, changes in haematocrit can be interpreted as a strategy to increase oxygen carrying capacity of the blood when fish are exposed to a stressful event (Ortuño, Estebán \& Meseguer, 2001). All of these could induce several changes in the cell blood composition (Guerra-Santos, Albinati, Moreira, Lima, de Azevedo, Costa, de Medeiros \& Lira, 2012), as reported by Del Rio-Zaragoza et al. (2011), for spotted rose snapper (Lutjanus guttatus Steindachner) infected by dactylogyrid monogeneans.

However, there were no statistical differences between treatments in this study for HTC and blood cell count. This is in agreement with the data obtained by Guerra-Santos et al. (2012) for cobia (Rachycentron canadum L.) infected with A. ocellatum, but we have to take in account that one possible explanation for these results could arise from the fact that haematological data on fish are quite difficult to interpret, mainly because of variations caused by both internal and external factors (Fazio, Filiciotto, Marafioti, Di Stefano, Assenza, Placenti, Buscaino, Piccione \& Mazzola, 2012). This could mask possible differences between treatments.

Regarding the immunological analysis, the lysozyme values indicate that there could be no innate immunological response to the presence of the parasite, which is in agreement with the results obtained for the contamination of gilthead seabream by other ectoparasites (Sitjà-Bobadilla, Calduch-Giner, Saera-Vila, Palenzuela, Álvarez-Pellitero \& Pérez-Sánchez, 2008; Guardiola, Cuesta, Arizcun, Meseguer \& Esteban, 2014; Henry, Nikoloudaki, Tsigenopoulos \& Rigos, 2015). This could be due to immuno-suppression of the hosts by the parasites by different strategies as exploitation of the immune system (Buchmann, 2000), evasion mechanisms based on antigen variation or mimicry, modification of the host's immune system, resistance to host's cellular or humoral factors (Rodriguez-Tovar, Wright, Wadowska, Speare \& Markham, 2002), or the development of a thick parasite tegument containing inhibitors of the complement cascade (Buchmann \& Lindenstrøm, 2002). 
The absence of significant differences in the values between treatments can also indicate the absence of a possible secondary bacterial infection (Guardiola et al., 2014).

In the proteomic analysis, the selected protein spots were identified as Apolipoprotein A-I (1 match), Hemopexin (2 matches), Uncharacterized protein OS Takifugu rubripes GN LOC101068102 PE 4 SV 1 (1 match), Uncharacterized protein OS Lepisosteus oculatus GN KRT9 2 of 3 PE 3 SV 1 (1 match) and Estrogen-regulated protein OS Sparus aurata PE 2 SV 1 (1 match). Apart from Estrogen-regulated protein OS Sparus aurata PE 2 SV 1, that has no known function, all other proteins are related to different metabolic functions, as lipid transport, osmoregulation and antioxidant activity, iron transport, immune system and cell injury, fibrinolysis, cellular and matrix interactions, inflammation, wound healing and neoplasia.

In lipid transport, we have identified several spots as Apolipoprotein A-I (ApoAI), as being down regulated in T1 gilthead sea bream plasma. This protein is produced in the liver and intestine (Llewellyn, Ramsurn, Wigham, Sweeney \& Power, 1998), and it is involved in lipid absorption in the intestine (Panzenbock, Kritharides, Raftery, Rye \& Stocker, 2000; Concha, Lopez, Villanueva, Baez \& Amthauer, 2005; Geay, Ferraresso, Zambonino-Infante, Bargelloni, Quentel, Vandeputte, Kaushik, Cahu \& Mazurais, 2011) and also in the transport of cholesterol to the liver by promoting cholesterol efflux from tissues and by acting as a cofactor for the lecithin cholesterol acyltransferase (Ibarz, Costa, Harrison \& Power, 2010; Geay et al., 2011). This could be related with the lipid metabolism in our study, as a reflex of lipid recruitment to metabolic processes (Geay et al., 2011). However, further studies would be needed in order to enlighten the role of this protein in the lipid metabolism of gilthead seabream exposed to A. ocellatum.

The protein ApoAI can also have antioxidant activity (Panzenbock et al., 2000) and osmoregulatory functions in teleosts (Smith, Wood, Cash, Diao \& Part, 2005), with a possible role in the hyperosmotic regulation on fish (Chen, Shi, Hu, Niu \& Li, 2009). Since Smith et al. (2005) correlate the expression of ApoAI as a determinant of the barrier properties of the freshwater fish 
gill (particularly in terms of modulating trans-cellular permeability the trans-cellular conductance in branchial epithelia) and Chen et al. (2009) indicate a downregulation of ApoAI when ayu (Plecoglossus altivelis Temminck \& Schlegel) passes from freshwater to brackish water, the observed downregulation of ApoAI can be related with the physiological impairment or epithelial damage of the branchia by A. ocellatum.

ApoAI could be involved in innate immunity response as antimicrobial protein (Concha, Molina, Oyarzún, Villanueva \& Amthauer, 2003; Concha, Smith, Castro, Bastias, Romero \& Amthauer, 2004; Sarropoulou, Sepulcre, Poisa-Beiro, Mulero, Meseguer, Figueras, Novoa, Terzoglou, Reinhardt, Magoulas \& Kotoulas, 2009; Rajan, Lokesh, Kiron \& Brinchmann, 2013) and can also have a role in the immunological response to certain ectoparasites in roho labeo (Labeo rohita $\mathrm{F}$. Hamilton), like Argulus siamensis (C. B. Wilson) (Mohapatra, Karan, Kar, Garg, Dixit \& Sahoo, 2016). This protein can also participate in inhibition of bacterial endotoxin, antiviral activity, antiinflammatory, anti-apoptotic role, inhibition of inflammatory cytokines, neutralization of LPS (Ulevitch, Johnston \& Weinstein, 1981; Johnston, Brown, Gauthier, Reece, Kator \& Van Veld, 2008) or associated with C3 complex in cod (Gadus morhua L.) (Magnadottir, 2006) and in rainbow trout (Oncorhynchus mykiss Walbaum) (Villarroel, Bastías, Casado, Amthauer \& Concha, 2007). The fact that usually an immune response is correlated with an increase or no change of ApoAI (Concha et al., 2003; Concha et al., 2004; Villarroel et al., 2007; Bo, Giesy, Ye, Wang, Lee \& Doris, 2012; Wu, Chen, Lin, Tzeng \& Chang, 2012) levels in plasma reinforces the possibility of an absence of response of the innate immune system to A. ocellatum, and also the possible absence of secondary bacterial infections.

Hemopexin is a protein with an important role in iron transport, being the plasma protein with the highest binding affinity to heme among known proteins. It is mainly expressed in liver, and is the major vehicle for the transportation of heme in the plasma, since it binds and transports heme to the liver for breakdown, thus preventing heme-mediated oxidative stress and heme-bound iron loss 
(Gracey, Troll \& Somero, 2001; Tolosano \& Altruda, 2002). Changes in the metabolism and sequestration of iron could be linked to hypoxia-induced erythropoiesis and increased demand for iron for hemoglobin synthesis (Gracey et al., 2001) or for the removal of free iron from the plasma, which is a potential source of iron for pathogens (Paoli, Anderson, Baker, Morgan, Smith \& Baker, 1999). The evolution of such a high affinity is a functional/structural response to the necessity of sequestering free heme within the blood stream with great efficiency (Paoli et al., 1999). The higher volume observed of this protein in $\mathrm{T} 1$ and $\mathrm{T} 2$ could indicate a response to anoxia caused by ectoparasites (Buchmann \& Lindenstrøm, 2002), that leads to an increased haemoglobin synthesis (Gracey et al., 2001) in order to cope with a possible increased in the production of erythrocytes.

There are several identified proteins in this work that are related with cell injury, fibrinolysis, cellular and matrix interactions, inflammation, wound healing and neoplasia mechanisms, mainly in acute phase response to inflammation and injury. Hemopexin is an acute phase reactant, and its synthesis can be induced after inflammation (Hirayama, Kobiyama, Kinoshita \& Watabe, 2004). The uncharacterized protein OS Takifugu rubripes GN LOC101068102 PE4 SV1, in which the closest ID by BLAST (http://www.uniprot.org/blast/uniprot/2014090493DNYK5ZU1) is fibrinogen beta chain protein, that plays an important role with fibrin in blood clotting (Geay et al., 2011), fibrinolysis, cellular and matrix interactions, inflammation, wound healing, neoplasia and can have an immune role in the liver of fish (Bohne-Kjersem, Skadsheim, Goksøyr \& Grøsvi, 2009; Xie, Zhang, Lin, Wang, Zou \& Wang, 2009). The overexpression of this protein in treatment T1 can be related to a response to the lesions produced by the ectoparasites in gilthead sea bream gills or because of their role as an acute phase protein, as a coagulation factor, as reporter by Bayne \& Gerwick (2001) and Tort et al. (2004).

The uncharacterized protein OS Lepisosteus oculatus GN KRT9 2 of 3 PE 3 SV 1, in which the closest ID by BLAST (http://www.uniprot.org/blast/uniprot/B2015092498OFPN8JTE?sort=eval\&desc $=$ false) is Keratin 1 , is a cytoskeletal protein whose primary function is to protect cells 
from mechanical and non-mechanical injuries (Coulombe \& Omary, 2002). Other report has also shown that keratin from fish mucus possesses antibacterial activity owing to its pore-forming properties (Molle, Campagna, Bessin, Ebran, Saint \& Molle, 2008). Keratin turnover is dependent on ubiquitin-proteasome pathway and its expression levels can be altered upon cell injury (Rogel, Jaitovich \& Ridge, 2010). The overexpression of this protein in $\mathrm{T} 1$ and $\mathrm{T} 2$ could be a response to cell injury by ectoparasites in this study.

\section{Conclusion}

All the identified proteins spots and the results obtained in the hematological analysis are part of a large physiological response of the gilthead sea bream to an A. occelatum outbreak.

One possible interpretation of the results is presented in figure 4.

Suggested location for figure 4

The presence of the parasite could induce a stress response by the fish (Landsberg et al., 1988). This can induce the activation of the acute phase response proteins, which is demonstrated in this work by the variation in volume of the spots related to the proteins hemopexin, fibrinogen beta chain protein and possibly keratin proteins.

We also know that parasites could possibly induce an innate immune response in fish (Tort, 2011). However, the results obtained in the hematological analysis are puzzling, since the presence of hemorrhages in the branchia (Lawler, 1980) could lead to differences in the HTC values, and the immune response to parasites (Tort, 2011) could also provoke some differences in WBC values. The absence of WBC and lysozyme levels could indicate that A. ocellatum can have an evasion 
system for the innate immune systems host and the inexistence of a bacterial secondary infection (Guardiola et al., 2014), which could explain the ApoAI variation.

The increase of hemopexin expression could indicate a higher quantity of free heme groups in the plasma, that can be delivered to the liver for iron recycling and reuse in the production of new erythrocytes (Concha et al., 2003). In this way the absence of differences in RBC in the HTC and differential cell count can be explained by erythrocyte synthesis in hematopoietic organs of fish.

The severe epithelial damage caused by the parasite $A$. ocellatum can also induce anoxia and osmoregulatory impairment in the organism (Lawler, 1980; Noga, 2012). This could explain the differential expression observed in the proteins with possible homeostasis and osmoregulatory functions (ApoAI), inflammation (fibrinogen beta chain, hemopexin), antioxidant activity (ApoAI), and wound healing and neoplasia (fibrinogen beta chain and keratin).

However, this is only a possible interpretation of the obtained results. Further studies will be needed to elucidate not only how these proteins are modulated along an A. ocellatum outbreak, but also to unravel other proteins involved in the physiological response of gilthead sea bream to this parasite.

Overall, this preliminary study revealed that amyloodiniosis affects the expression of proteins with known functions on the acute phase response mechanism, and physiological responses related with inflammation, lipid transport, homeostasis, osmoregulation, wound healing, inflammation, neoplasia, antioxidant activity, and iron transport in gilthead sea bream exposed to A. ocellatum. Some of this data were also confirmed by the hematological and immunological parameter analysis. Further interdisciplinary studies will be needed to elucidate the role of these proteins in an amyloodiniosis outbreak. 
This was the first time that proteomics was used for the assessment of the physiological changes in the plasma of fishes exposed to A. ocellatum. The results obtained demonstrate that proteomics can be an excellent tool for a wider analysis of the physiological responses to A. ocellatum outbreaks.

The outcome of this work, even if preliminary, can be the origin of future works. They could not only improve the knowledge about the physiological response of fish to this parasite, but also help to develop new products to improve the physiological resistance of fish to A. ocellatum.

\section{Acknowledgments}

This work has been financially supported by project BONAQUA (0433_BONAQUA_5_E).

\section{References}

Alves R.N., Cordeiro O., Silva T.S., Richard N., de Vareilles M., Marino G., Di Marco P., Rodrigues P.M., Conceição L.E.C. (2010) Metabolic molecular indicators of chronic stress in gilthead seabream (Sparus aurata) using comparative proteomics. Aquaculture 299(1-4), 57-66.

Aravindan N., Chaganti K., Aravindan S. (2007) Protozoan parasites in commercially important shrimp species from northeast coast of Andhra Pradesh, India. Journal of Experimental Zoology 10(1), 9-20.

Bayne C.J., Gerwick L. (2001) The acute phase response and innate immunity of fish. Developmental \& Comparative Immunology 25, 725-43. 
Becker C.D. (1977) Flagellate parasites of fishes. In: Parasitic Protozoa (ed. by J.P. Krier), pp. 357-416, Academic Press, New York.

Bo J., Giesy J.P., Ye R., Wang K.-J., Lee J.-S., Doris W.T.A. (2012) Identification of differentially expressed genes and quantitative expression of complement genes in the liver of marine medaka Oryzias melastigma challenged with Vibrio parahaemolyticus. Comparative Biochemistry and Physiology Part D: Genomics and Proteomics 7, 191-200.

Bohne-Kjersem A., Skadsheim A., Goksøyr A., Grøsvi, B.E. (009). Candidate biomarker discovery in plasma of juvenile cod (Gadus morhua) exposed to crude North Sea oil, alkyl phenols and polycyclic aromatic hydrocarbons (PAHs). Marine Environmental Research 68, 268-77.

Brown E.M., Hovasse R. (1946) Amyloodinium ocellatum Brown, a peridinian parasite on marine fishes: A complementary study. Proceedings of The Zoological Society of London 116, 33-46.

Buchmann K. (2000) Antiparasitic immune mechanisms in teleost fish: a two-edged sword? Bulletin- European Association of Fish Pathologists 20, 48-59.

Buchmann K., Lindenstrøm T. (2002) Interactions between monogenean parasites and their fish hosts. International Journal for Parasitology 32, 309-319.

Buscaino G., Filiciotto F., Buffa G., Bellante A., Di Stefano V., Assenza A., Fazio F., Caola G., Mazzola S. (2010) Impact of an acoustic stimulus on the motility and blood parameters in European sea bass (Dicentrarchus labrax L.) and gilthead sea bream (Sparus aurata L.). Marine Environmental Research 69,136-142. 
Chen J., Shi Y.H., Hu H.Q., Niu H., Li M.Y. (2009) Apolipoprotein A-I, a hyperosmotic adaptation-related protein in ayu (Plecoglossus altivelis). Comparative Biochemistry and Physiology Part B: Biochemistry and Molecular Biology 152, 196-201.

Clauss T., Dove A., Arnold J. (2008) Hematologic disorders of fish. The veterinary clinics of North America: Exotic Animal Practice 11, 445-462.

Cobb C.S., Levy M.G., Noga E.J. (1998) Acquired immunity to amyloodinosis is associated with an antibody response. Diseases of Aquatic Organisms 34, 125-133.

Colorni A. (1994) Hyperparasitism of Amyloodinium ocellatum (Dinoflagellida: Oodinidae) on Neobenedenia melleni (Monogenea: Capsalida). Diseases of Aquatic Organisms 19, 157-159.

Colorni A., Ullal A., Heinisch G., Noga E.J. (2008) Activity of the antimicrobial polypeptide piscidin 2 against fish ectoparasites. Journal of Fish Diseases 31, 423-32.

Concha M.I., Molina S., Oyarzún C., Villanueva J., Amthauer R. (2003) Local expression of apolipoprotein A-I gene and a possible role for HDL in primary defence in the carp skin. Fish and Shellfish Immunology 14, 259-73.

Concha M.I., Smith V.J., Castro K., Bastias A., Romero A., Amthauer R. (2004) Apolipoproteins A-I and A-II are potentially important effectors of innate immunity in the teleost fish Cyprinus carpio. European Journal of Biochemistry 271, 2984-2990.

Concha M.I., Lopez R., Villanueva J., Baez N., Amthauer R. (2005) Undetectable apolipoprotein A-I gene expression suggests an unusual mechanism of dietary lipid mobilisation in the intestine of Cyprinus carpio. The Journal of Experimental Biology 208, 1393-1399. 
Corrales J., Mulero I., Mulero V., Noga E.J. (2010) Detection of antimicrobial peptides related to piscidin 4 in important aquacultured fish. Developmental and Comparative Immunology 34, 331343.

Coulombe P.A., Omary M.B. (2002) 'Hard' and 'soft' principles defining the structure, function and regulation of keratin intermediate filaments. Current Opinion in Cell Biology 14, 110-22.

Cox J., Mann M. (2011) Quantitative, high-resolution proteomics for data-driven systems biology. Annual Review of Biochemistry 80, 273-99.

Cristina García Diez C., Remiro Perlado J.P. (2014) Impactos del Cambio Climático sobre la Acuicultura en España. Oficina Española de Cambio Climático, Ministerio de Agricultura, Alimentación y Medio Ambiente. Madrid.

Cruz-Lacierda E.R., Maeno Y., Pineda A.J.T., Matey V.E. (2004) Mass mortality of hatcheryreared milkfish (Chanos chanos) and mangrove red snapper (Lutjanus argentimaculatus) caused by Amyloodinium ocellatum (Dinoflagellida). Aquaculture 236, 85-94.

Del Rio-Zaragoza O.B., Hernandez-Rodriguez M., Buckle-Ramirez L.F. (2008) Thermal stress effect on tilapia Oreochromis mossambicus (Pisces: Cichlidae) blood parameters. Marine and Freshwater Behaviour and Physiology 41, 135-145.

Del Rio-Zaragoza O.B., Fajer-Avila E.J., Almazan-Rueda P., Abdo de la Parra M.I. (2011) Hematological characteristics of the spotted rose snapper Lutjanus guttatus (Steindachner, 1869) healthy and naturally infected by dactylogyrid monogeneans. Tissue and Cell 43, 137-142. 
Ellis A.E. (1990) Lysozyme assays. In: Techniques in fish immunology (ed. by J.S. Stolen, T.C. Fletcher, D.P. Anderson, B.S. Roberson, W.B. Van Muiswinkel), pp. 101-103, SOS Publications, Fair Haven, NJ.

FAO (2014) Food Outlook. Biannual Report on Global Food Markets - October 2014. Rome.

FAO (2015). Coping with climate change - the roles of genetic resources for food and agriculture. Rome.

FAO (2016) The State of World Fisheries and Aquaculture 2016 (SOFIA). Rome.

Fazio F., Filiciotto F., Marafioti S., Di Stefano V., Assenza A., Placenti F., Buscaino G., Piccione G., Mazzola S. (2012) Automatic analysis to assess haematological parameters in farmed gilthead sea bream (Sparus aurata Linnaeus, 1758). Marine and Freshwater Behaviour and Physiology 45(1), 63-73.

FOESA (2013) Cambio climático y acuicultura. Madrid.

Geay F., Ferraresso S., Zambonino-Infante J., Bargelloni L., Quentel C., Vandeputte M., Kaushik S., Cahu C., Mazurais D. (2011) Effects of the total replacement of fish-based diet with plant-based diet on the hepatic transcriptome of two European sea bass (Dicentrarchus labrax) half-sibfamilies showing different growth rates with the plant-based diet. BMC Genomics 12, 522.

Gracey A.Y., Troll J.V., Somero G.N. (2001) Hypoxia-induced gene expression profiling in the euryoxic fish Gillichthys mirabilis. PNAS 98(4), 1993-1998. 
Guardiola F.A., Cuesta A., Arizcun M., Meseguer J., Esteban M.A. (2014) Comparative skin mucus and serum humoral defence mechanisms in the teleost gilthead seabream (Sparus aurata). Fish \& Shellfish Immunology 36(2), 545-551.

Guerra-Santos B., Albinati R.C.B., Moreira E.L.T, Lima F.W.M., de Azevedo T.M.P, Costa D.S.P., de Medeiros S.D.C., Lira A.D. (2012) Parâmetros hematológicos e alterações histopatológicas em bijupirá (Rachycentron canadum Linnaeus, 1766) com amyloodiniose. Pesquisa Veterinária Brasileira 32(11), 1184-1190.

Henry M.A., Nikoloudaki C., Tsigenopoulos C., Rigos G. (2015) Strong effect of long-term Sparicotyle chrysophrii infection on the cellular and innate immune responses of gilthead sea bream, Sparus aurata. Developmental \& Comparative Immunology 51(1), 185-193.

Hirayama M., Kobiyama A., Kinoshita S., Watabe S. (2004) The occurrence of two types of hemopexin-like protein in medaka and differences in their affinity to heme. The Journal of Experimental Biology 207, 1387-1398.

Ibarz A., Costa R., Harrison A.P., Power D.M. (2010). Dietary keto-acid feed-back on pituitary activity in gilthead sea bream: Effects of oral doses of AKG. A proteomic approach. General and Comparative Endocrinology 169, 284-92.

Isani G., Andreani G., Carpenè E., Di Molfetta S., Eletto D., Spisni E. (2011) Effects of waterborne $\mathrm{Cu}$ exposure in gilthead sea bream (Sparus aurata): A proteomic approach. Fish and Shellfish Immunology 31, 1051-58. 
Johnston L.D., Brown G., Gauthier D., Reece K., Kator H., Van Veld P. (2008) Apolipoprotein A-I from striped bass (Morone saxatilis) demonstrates antibacterial activity in vitro. Comparative Biochemistry and Physiology Part B: Biochemistry and Molecular Biology 151, 167-75.

Joyce A.R., Palsson B.O. (2006) The model organism as a system: integrating 'omics' data sets. Nature Reviews Molecular Cell Biology 7, 198-210.

Karlson B., Caroline C., Bresnan E. (2010) Microscopic and molecular methods for quantitative phytoplankton analysis. IOC Manuals and guides 113, UNESCO.

Kuperman B.L., Matey V.E. (1999) Massive infestation by Amyloodinium ocellatum (Dinoflagellida) of fish in a highly saline lake, Salton Sea, California, USA. Diseases of Aquatic Organisms 39, 65-73.

Landsberg J.H., Blakesley B.A., Reese R.O., Mcrae G., Forstchen P.R. (1988) Parasites of fish as indicators of environmental stress. Environmental Monitoring and Assessment 51, 211-232.

Lauckner G. (1984) Diseases caused by protophytans (algae). In: Diseases of Marine Animals, Vol. IV, Part 1 (ed. by O. Kinne), pp.169-180, Biologische Anstalt Helgoland, Hamburg, Germany.

Lawler A.R. (1980) Studies on Amyloodinium ocellatum (Dinoflagellata) in Mississippi Sound: natural and experimental hosts. Gulf Research Reports 6, 403-413.

Lem A., Bjorndal T., Lappo A. (2014) Economic analysis of supply and demand for food up to 2030 - Special focus on fish and fishery products. FAO Fisheries and Aquaculture Circular $N^{\circ}$. 1089, 106 pp. Rome, FAO. 
Llewellyn L., Ramsurn V.P., Wigham T., Sweeney G.E., Power D.M. (1998) Cloning, characterisation and expression of the apolipoprotein A-I gene1 in the sea bream (Sparus aurata). Biochimica et Biophysica Acta (BBA) - Gene Structure and Expression 1442, 399-404.

Loot G., Poulet N., Brosse S., Tudesque L., Thomas F., Blanchet S. (2011) Determinants of lifehistory traits in a fish ectoparasite: a hierarchical analysis. Parasitology 138, 848-857.

Magnadottir B. (2006) Innate immunity of fish (overview). Fish and Shellfish Immunology 20, 13751.

Marcogliese D.J. (2008) The impact of climate change on the parasites and infectious diseases of aquatic animals. Revue scientifique et technique (International Office of Epizootics) 27, 467-84.

Martyniuk C.J., Alvarez S., Denslow N.D. (2012) DIGE and iTRAQ as biomarker discovery tools in aquatic toxicology. Ecotoxicology and Environmental Safety 76, 3-10.

Mladineo I., Petrić M., Šegvić T., Dobričić N. (2010) Scarcity of parasite assemblages in the Adriatic-reared European sea bass (Dicentrarchus labrax) and sea bream (Sparus aurata). Veterinary Parasitology 174 (1-2), 131-138.

Mohan C. (2015) Climate Change and Aquatic Animal Disease. Submission from the International Center for Tropical Agriculture (CIAT) on behalf of the CGIAR Research Program on Climate Change, Agriculture and Food Security (CCAFS), to UNFCCC SBSTA 42 on issues related to agriculture in response to SBSTA decision FCC/SBSTA/2014/L.14.

Mohapatra A., Karan S., Kar B., Garg L.C., Dixit A., Sahoo P.K. (2016) Apolipoprotein A-I in Labeo rohita: Cloning and functional characterisation reveal its broad spectrum antimicrobial 
property, and indicate significant role during ectoparasitic infection. Fish \& Shellfish Immunology 55, 717-728.

Molle V., Campagna S., Bessin Y., Ebran N., Saint N., Molle G. (2008) First evidence of the poreforming properties of a keratin from skin mucus of rainbow trout (Oncorhynchus mykiss, formerly Salmo gairdneri). Biochemistry Journal 411, 33-40.

Murray A.G., Peeler E.J. (2005) A framework for understanding the potential for emerging diseases in aquaculture. Preventive Veterinary Medicine 67, 223-235.

Noga E.J., Fan Z., Silphaduang U. (2002) Host site of activity and cytological effects of histone-like proteins on the parasitic dinoflagellate Amyloodinium ocellatum. Diseases of Aquatic Organisms 52, 207-15.

Noga E.J. (2006) Fish Disease: Diagnosis and Treatment. Iowa State University Press, Ames, Iowa.

Noga E.J., Silphaduang U., Park N.G., Seo J.K., Stephenson J., Kozlowicz S. (2009) Piscidin 4, a novel member of the piscidin family of antimicrobial peptides. Comparative Biochemistry and Physiology Part B: Biochemistry and Molecular Biology 152, 299-305.

Noga E.J., Ullal A.J., Corrales J., Fernandes J.M. (2011) Application of antimicrobial polypeptide host defenses to aquaculture: Exploitation of downregulation and upregulation responses. Comparative Biochemistry and Physiology Part D: Genomics and Proteomics 6, 44-54.

Noga E.J. (2012) Amyloodinium ocellatum. In: Fish Parasites - Pathobiology and Protection (ed. by K. Buchmann, P.T.K. Woo), pp. 19-29, CABI Publishers, Preston, UK. 
Ortuño J., Estebán M.A., Meseguer J. (2001) Effects of short-term crowding stress on the gilthead seabream (Sparus aurata L.) innate immune response. Fish and Shellfish Immunology 11, 187197.

Panzenbock U., Kritharides L., Raftery M., Rye K.A., Stocker R. (2000) Oxidation of methionine residues to methionine sulfoxides does not decrease potential antiatherogenic properties of apolipoprotein A-I. Journal of Biological Chemistry 275, 19536-19544.

Paoli M., Anderson B.F., Baker H.M., Morgan W.T., Smith A., Baker E.N. (1999) Crystal structure of hemopexin reveals a novel high- affinity heme site formed between two $\beta$-propeller domains. Nature Structural \& Molecular Biology 6, 926-931.

Paperna I., Colorni A., Ross B., Colorni B. (1981) Diseases of marine fish cultured in Eilat mariculture project based at the Gulf of Aqaba, Red Sea. European Mariculture Society Special Publication 6, 81-91.

Peng X.X. (2013) Proteomics and its applications to aquaculture in China: infection, immunity, and interaction of aquaculture hosts with pathogens. Developmental \& Comparative Immunology 39, $63-71$.

Percin F., Konyalioglu S. (2008) Serum Biochemical Profiles of Captive and Wild Northern Bluefin Tuna, (Thunnus thynnus L. 1758) in the Eastern Mediterranean. Aquaculture Research 39, 945-953.

R Core Team (2013) R: A language and environment for statistical computing. R Foundation for Statistical Computing, Vienna, Austria, URL http://www.R-project.org/. 
Rajan B., Lokesh J., Kiron V., Brinchmann M. (2013) Differentially expressed proteins in the skin mucus of Atlantic cod (Gadus morhua) upon natural infection with Vibrio anguillarum. BMC Veterinary Research 9, 103.

Rodrigues P.M., Silva T.S., Dias J., Jessen F. (2012) PROTEOMICS in aquaculture: Applications and trends. Journal of Proteomics 75(14), 4325-4345.

Rodriguez-Tovar L.E., Wright G.M., Wadowska D.W., Speare D.J., Markham R.J.F. (2002) Ultrastructural study of the early development and localization of Loma salmonae in the gills of experimentally infected rainbow trout. Journal of Parasitology 88, 244-253.

Rogel M.R., Jaitovich A., Ridge K.M. (2010) The Role of the Ubiquitin Proteasome Pathway in Keratin Intermediate Filament Protein Degradation. Proceedings of the American Thoracic Society 7, 71-76.

Sarropoulou E., Sepulcre P., Poisa-Beiro L., Mulero V., Meseguer J., Figueras A., Novoa B., Terzoglou V., Reinhardt R., Magoulas A. Kotoulas, G. (2009) Profiling of infection specific mRNA transcripts of the European seabass Dicentrarchus labrax. BMC Genomics 10, 157.

Saurabh S., Sahoo P.K. (2008) Lysozyme: an important defence molecule of fish innate immune system. Aquaculture Research 39, 223-239.

Shinn A.P., Pratoomyot J., Bron J.E., Paladini G., Brooker E.E., Brooker A.J. (2015). Economic costs of protistan and metazoan parasites to global mariculture. Parasitology 142, 196-270.

Sitjà-Bobadilla A., Calduch-Giner J., Saera-Vila A., Palenzuela O., Álvarez-Pellitero P., PérezSánchez J. (2008) Chronic exposure to the parasite Enteromyxum leei (Myxozoa: Myxosporea) 
modulates the immune response and the expression of growth, redox and immune relevant genes in gilthead sea bream, Sparus aurata L.. Fish \& Shellfish Immunology 24(5), 610-619.

Smith R.W., Wood C.M., Cash P., Diao L., Part P. (2005) Apolipoprotein AI could be a significant determinant of epithelial integrity in rainbow trout gill cell cultures: a study in functional proteomics. Biochimica et Biophysica Acta 1749, 81-93.

Smith S.A., Levy M.G., Noga E.J. (1992) Development of an enzyme-linked immunosorbent assay (ELISA) for the detection of antibody to the parasitic dinoflagellate Amyloodinium ocellatum in Oreochromis aureus. Veterinary Parasitology 42, 145-155.

Smith S.A., Levy M.G., Noga E.J. (1994) Detection of Anti-Amyloodinium ocellatum Antibody from Cultured Hybrid Striped Bass (Morone saxatilis $\times$ M. chrysops) during an Epizootic of Amyloodiniosis. Journal of Aquatic Animal Health 6, 79-81.

Soares F., Quental-Ferreira H., Cunha E., Pousão-Ferreira P. (2011) Occurrence of Amyloodinium ocellatum in aquaculture fish production: a serious problem in semi-intensive earthen ponds. Aquaculture Europe 2011 36(4), 13-16.

Soares F., Leitão A., Moreira M., Teixeira de Sousa J., Almeida A.C., Barata M., Feist S.W., Pousão-Ferreira P., Ribeiro L. (2012) Presence of sarcoma in the thymus of meagre juveniles (Argyrosomus regius, Asso) reared in intensive system. Diseases of Aquatic Organisms 102, 119127.

The World Bank (2013) Fish to 2030 - Prospects for Fisheries and Aquaculture. World Bank Report Number 83177-GLB, Agriculture and Environmental Services Discussion Paper 03. 
Tolosano E., Altruda F. (2002) Hemopexin: Structure, Function, and Regulation. DNA and Cell Biology 21(4), 297-306.

Tort L., Balasch J.C., MacKenzie S. (2004) Fish health challenge after stress - indicators of immunocompetence. Contributions to Science 2, 443-54.

Tort L. (2011). Stress and immune modulation in fish. Developmental \& Comparative Immunology 35(12), 1366-1375.

Ulevitch R.J., Johnston A.R., Weinstein D.B. (1981) New function for high density lipoproteins. Isolation and characterization of a bacterial lipopolysaccharide-high density lipoprotein complex formed in rabbit plasma. Journal of Clinical Investigation 67, 827-37.

Vidal-Martínez V.M., Pech D., Sures B., Purucker S.T., Poulin R. (2009) Can parasites really reveal environmental impact? Trends in Parasitology 26(1), 44-51.

Villarroel F., Bastías A., Casado A., Amthauer R., Concha M.I. (2007) Apolipoprotein A-I, an antimicrobial protein in Oncorhynchus mykiss: Evaluation of its expression in primary defence barriers and plasma levels in sick and healthy fish. Fish and Shellfish Immunology 23, 197-209.

Woo P.T.K. (2007) Protective immunity in fish against protozoan diseases. Parassitologia 49, 185191.

Woo P.T.K., Ardelli B.F. (2014) Immunity against selected piscine flagellates. Developmental \& Comparative Immunology 43, 268-279.

Wu M.S., Chen C.W., Lin C.H., Tzeng C.S., Chang C.Y. (2012) Differential expression profiling of orange-spotted grouper larvae, Epinephelus coioides (Hamilton), that survived a betanodavirus outbreak. Journal of Fish Diseases 35, 215-225. 
Xie F.J., Zhang Z.P., Lin P., Wang S.H., Zou Z.H., Wang Y.L. (2009) Identification of immune responsible fibrinogen beta chain in the liver of large yellow croaker using a modified annealing control primer system. Fish and Shellfish Immunology 27, 202-209. 


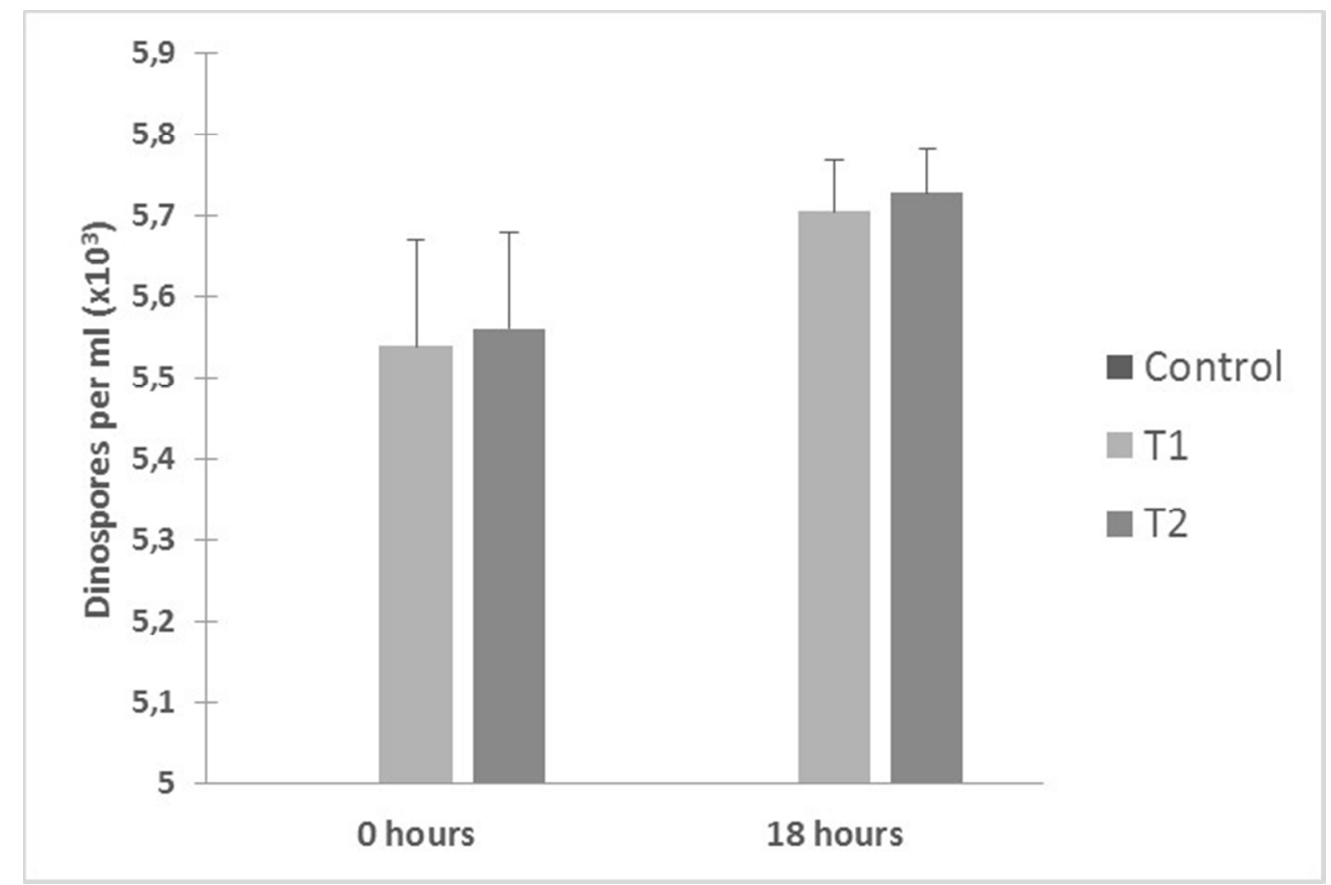

Figure 1 - Amyloodinium ocellatum dinospores concentration in the water from different treatments, $\mathrm{T} 1, \mathrm{~T} 2$ and Control ( $\mathrm{N}=11$, Error bars= standard deviation).

$151 \times 101 \mathrm{~mm}(118 \times 118 \mathrm{DPI})$ 


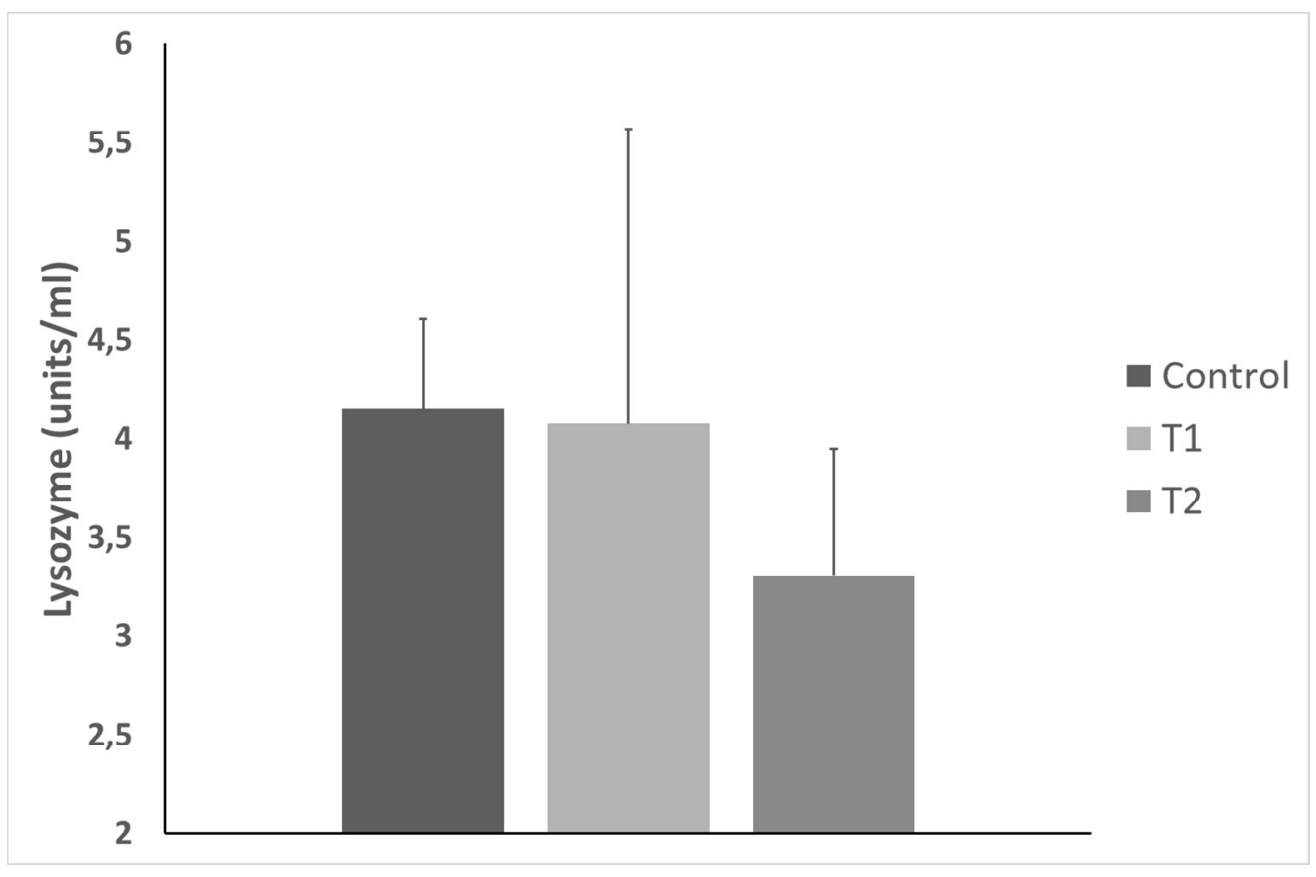

Figure 2 - Lysozyme values obtained from gilthead sea bream (Sparus aurata) plasma ( $N=11$, Error bars= standard deviation, $a=0.05$ ).

$258 \times 169 \mathrm{~mm}(150 \times 150 \mathrm{DPI})$ 


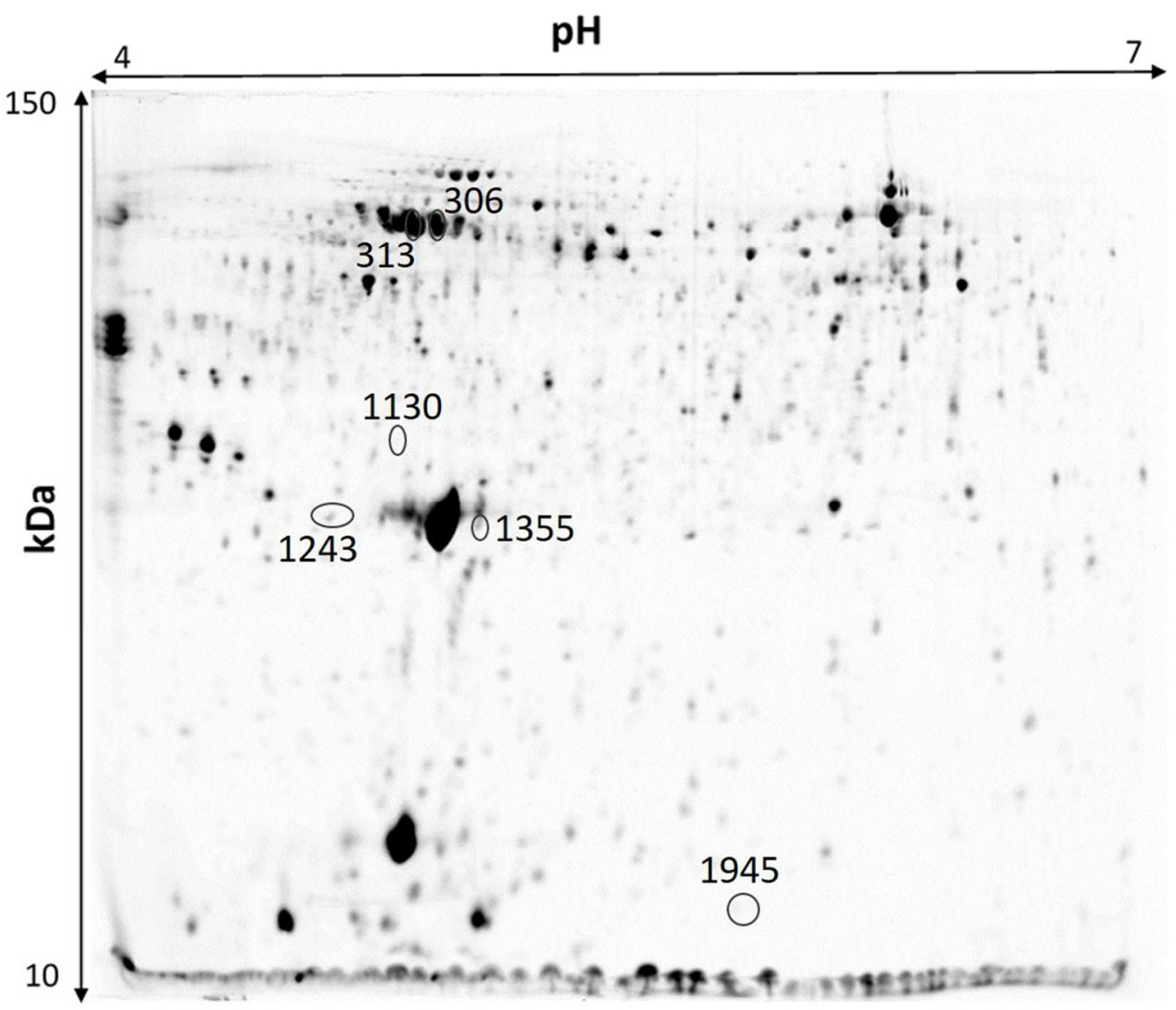

Figure 3 - Representative 2D PAGE of gilthead sea bream (Sparus aurata) plasma. The pointed circles with numbers represent the spots selected for protein analysis.

$187 \times 160 \mathrm{~mm}(150 \times 150 \mathrm{DPI})$ 
Table 1 - HTC results for gilthead sea bream (Sparus aurata) blood $(\mathrm{N}=11)$.

\begin{tabular}{|l|c|c|c|}
\hline & Control & Treatment 1 & Treatment 2 \\
\hline Red blood cells $(\mathrm{mm})$ & $\mathbf{1 8 , 8} \pm 0,23$ & $\mathbf{1 8 , 6} \pm 0,27$ & $\mathbf{2 2 , 6} \pm 0,44$ \\
\hline Buffy coat $(\mathrm{mm})$ & $0,43 \pm 0,41$ & $0,14 \pm 0,28$ & $0 \pm 0$ \\
\hline
\end{tabular}


Table 2 - Blood cell counts for gilthead sea bream (Sparus aurata) blood (N=11).

\begin{tabular}{|l|c|c|c|}
\hline & Control & Treatment 1 & Treatment 2 \\
\hline RBC (\%) & $97,87 \pm 1,72$ & $98,34 \pm 1,05$ & $98,49 \pm 0,64$ \\
\hline WBC (\%) & $0,99 \pm 0,45$ & $0,92 \pm 0,26$ & $1,52 \pm 0,27$ \\
\hline Leucocytes (\%) & $0,61 \pm 0,92$ & $0,26 \pm 0,33$ & $0,54 \pm 0,40$ \\
\hline Monocytes (\%) & $0,38 \pm 0,54$ & $0,31 \pm 0,28$ & $0,33 \pm 0,35$ \\
\hline Neutrophyles (\%) & $0,20 \pm 0,49$ & $0,14 \pm 0,18$ & $0,17 \pm 0,21$ \\
\hline Eosinophyles (\%) & $0,05 \pm 0,13$ & $0,15 \pm 0,17$ & $0,12 \pm 0,23$ \\
\hline Basophyles (\%) & $0,07 \pm 0,18$ & $0,06 \pm 0,35$ & $0,25 \pm 0,32$ \\
\hline Trombocytes (\%) & $0,81 \pm 1,22$ & $0,74 \pm 0,84$ & $0,11 \pm 0,21$ \\
\hline
\end{tabular}


हิ

ป

क्ते

E.

해

\&.

墕

吾矛

岁

है

존 옹

$\stackrel{0}{0}$

$\Xi$

용

䒕 灵

잉

촐

过

跑莺

$\sum_{\text {in }}^{n}$

$\sum_{1}^{\infty} \boxminus$

㻤

글

包

营

की

흥

흘

을

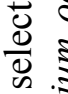

홍

to요

을

อั สิ

in 范

m.

ब串
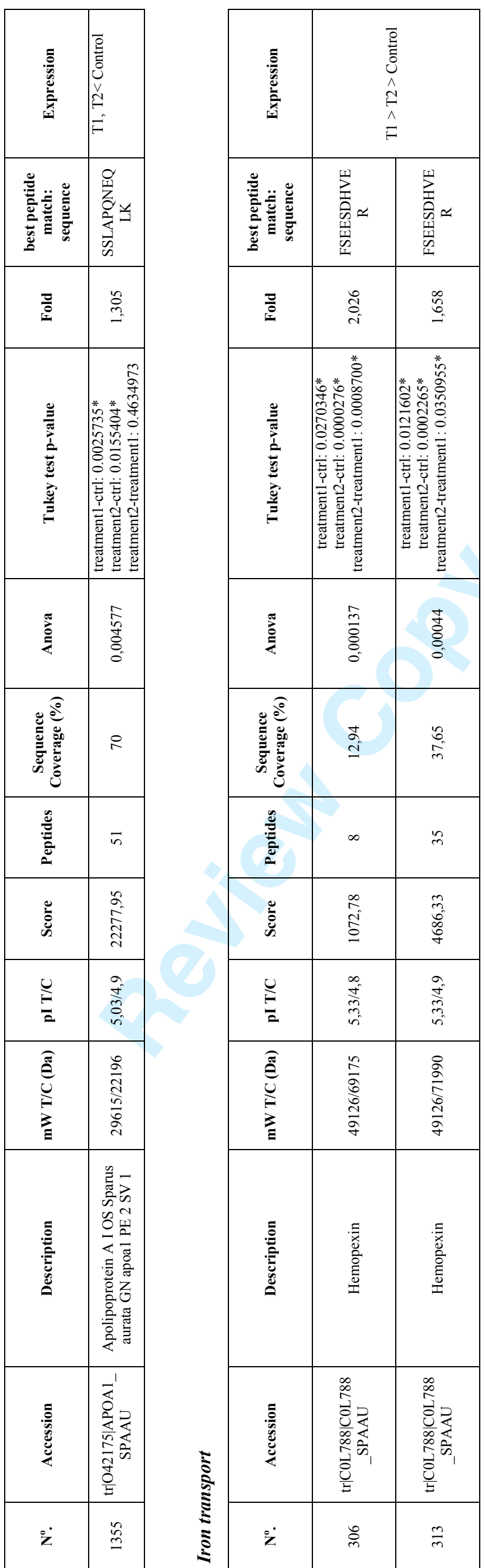

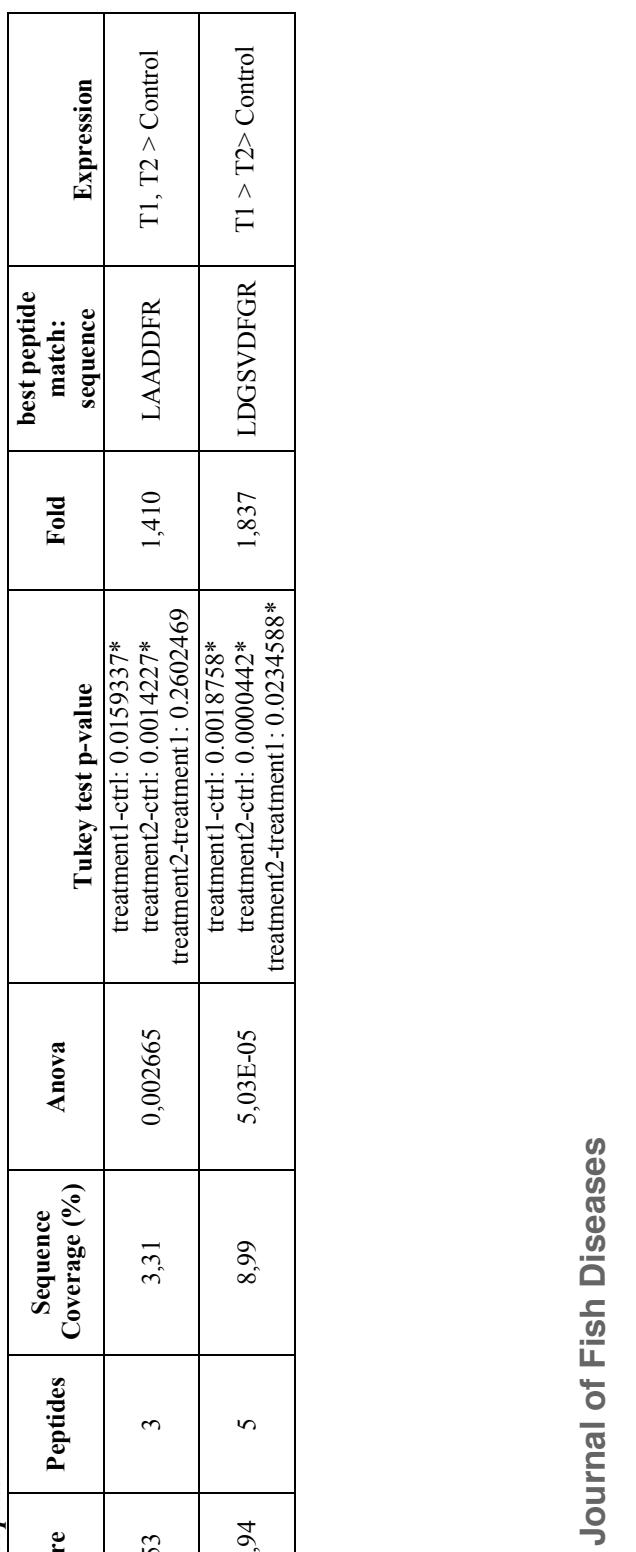

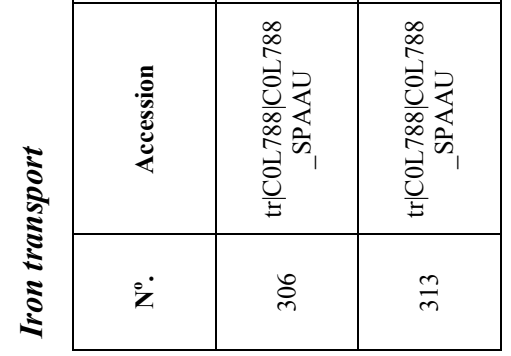




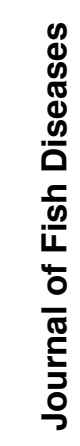

\begin{tabular}{|c|c|}
\hline 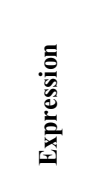 & $\begin{array}{l}\overrightarrow{\bar{E}} \\
\text { है } \\
\hat{0} \\
\hat{E} \\
\vec{H}\end{array}$ \\
\hline 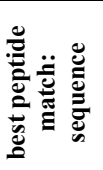 & 总 \\
\hline 흥 & 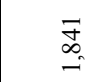 \\
\hline 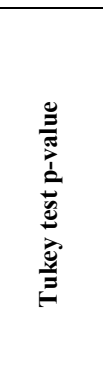 & 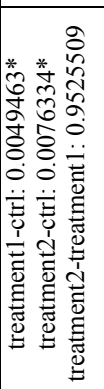 \\
\hline 音 & $\begin{array}{l}\hat{\mathrm{a}} \\
\text { 亏े } \\
\text { o. }\end{array}$ \\
\hline 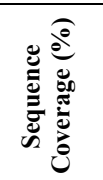 & $\begin{array}{l}\stackrel{n}{2} \\
\stackrel{2}{ \pm}\end{array}$ \\
\hline 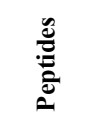 & $n$ \\
\hline 离 & $\frac{\sqrt[n]{3}}{\overrightarrow{5}}$ \\
\hline$\frac{\vartheta}{a}$ & $\begin{array}{l}n \\
\stackrel{n}{g} \\
\dot{g} \\
\dot{f}\end{array}$ \\
\hline 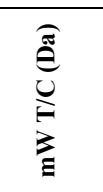 & 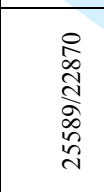 \\
\hline 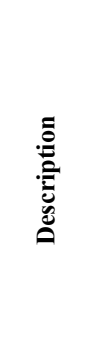 & 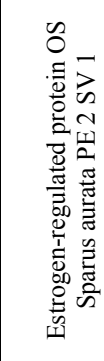 \\
\hline 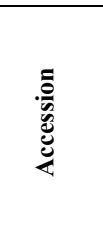 & 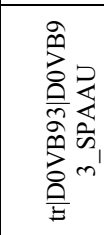 \\
\hline$\stackrel{\dot{z}}{ }$ & $\stackrel{\text { I }}{\Xi}$ \\
\hline
\end{tabular}

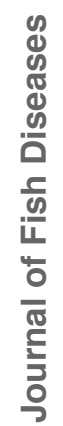

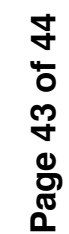


